\title{
Mortality study of British pathologists 1974-80
}

\author{
J M HARRINGTON ${ }^{1}$ AND D OAKES ${ }^{2}$ \\ From the Institute of Occupational Health, ${ }^{1}$ University of Birmingham, Birmingham B15 2TJ, and the TUC \\ Centenary Institute of Occupational Health, ${ }^{2}$ London School of Hygiene and Tropical Medicine, London \\ WCIE $7 H T, U K$
}

\begin{abstract}
Membership lists of the Royal College of Pathologists from 1974 to 1980 were used to establish a population of 2307 men and 413 women. During the period of study 126 of these pathologists died and death certificates were obtained for 121 . The standardised mortality ratios (SMR) for all causes in men were 56 and in women 99. Deaths from accidents, poisoning, violence, and especially suicide, were noted to be in excess of that expected from the general population but similar to that for medical practitioners. Drug overdose was the cause of each suicide. Excess deaths from lymphatic and haemopoietic neoplasms noted in a previous study were not present but an excess of brain tumours was found. Including 1981 data thus far collected, deaths from brain tumour were apparently in excess (observed 6 , expected $<2 \cdot 0$, $\mathrm{p}<0.02$ ). Possible aetiological hypotheses include previous exposure to organic solvents or tuberculosis infection. In view of the pathologists' exposure to formaldehyde it is interesting to note that no nasal or nasal sinus tumours were reported and the SMR for lung cancer was 41 .
\end{abstract}

Reports on laboratory health and safety contain many examples of laboratory hazards, but few attempts have been made to determine the mortality experience of a population of laboratory workers. Reid undertook an incidence study of tuberculosis in medical laboratory workers ${ }^{1}$ and also carried out a mortality study of members of the Pathological Society or the Association of Clinical Pathologists in Britain for the period 1905-54. His analysis of 300 deaths showed a threefold excess mortality from suicide compared with those expected from social class I, although no specific neoplastic risks were cited. A subsequent study covering the period 1955-73 and using the same population sources as well as the newly formed Royal College of Pathologists* noted excess mortality rates for suicide and lymphatic and haemopoietic neoplasms, though no clustering was noted within any one pathology subspecialty. ${ }^{2}$ Excess mortality or tumour incidence rates for lymphoma have also been noted in chemists in the United States ${ }^{3}$ and Sweden, ${ }^{4}$ whereas an excess of

*Eligibility for membership of the Royal College of Pathologists implies at least two years' postgraduate experience in the subject, and members will include all hospital based specialists in microbiology, haematology, morbid anatomy, and clinical chemistry. Most members will be medically qualified.

Received 9 December 1982

Accepted 18 March 1983
Hodgkins disease has been noted in doctors, ${ }^{5}$ and both Hodgkins and non-Hodgkins lymphoma in "medical workers."

In addition, pathologists have been exposed to several known or suspected bladder carcinogens such as benzidine and O-toluidine, and one study of British chemists suggested a possible link to brain tumours and reticuloendothelial tumours. ${ }^{7}$ The recent concern over the possible carcinogenicity of formaldehyde ${ }^{8}$ has further fuelled interest in the pathology laboratory as a source of occupationally induced neoplasia. Thus we have undertaken a follow up study on the population of British pathologists starting when the previous investigation ended.

\section{Method}

A list was established of all United Kingdom members of the Royal College of Pathologists who appeared in the 1973 yearbook and were alive on 31 December 1973. This list was traced through successive yearbooks and new entrants added until 31 December 1980. The vital status of this population was established using the facilities of the General Medical Council, the National Health Service Registries at Southport and Edinburgh, and the Office of Population Censuses and Surveys.

Person-years of follow up accumulated by the study population in 1974-80 inclusive were calcu- 
lated within five year age and single year calendar intervals. These were multiplied by the age, sex, and time specific death rates for England and Wales, Scotland, or Northern Ireland as appropriate to calculate expected deaths. Comparisons of observed with expected deaths were made from all causes and from specific causes. Foreign members of the college were excluded but emigrants and immigrants were included for the period they were in the United Kingdom. Deaths occurring in 1974-8 were coded according to the eighth revision of the International Classification of Diseases (ICD); those in 1979 and 1980 according to the ninth revision. All causes of death mentioned on the certificate were coded, although the comparison of observed and expected deaths was made for the underlying cause only.

\section{Results}

The study population comprised 2307 men and 413 women with mean ages 49.6 years and 46.4 years respectively. Confirmation of vital status was achieved for 2304 men $(99.9 \%)$ and 411 women $(99.5 \%)$. A total of 121 death certificates was obtained and five were untraced (96\% trace rate). In three of these five cases the pathologists's name still appeared on the list of a family practitioner committee, despite strong evidence from the RCPath indicating his or her demise.

Table 1 shows the observed and expected deaths from all causes and from certain specific causes separately for men and women. The specific causes are those either investigated in the previous study ${ }^{2}$ or for which evidence existed from other studies warranting analysis. The corresponding standardised mortality ratios (SMR) for observed deaths as a percentage of expected deaths are also listed together with two sided $90 \%$ confidence intervals for the SMRs calculated from the limits of the expectation of a Poisson variable. Exact one-sided significance levels were calculated on the basis of a Poisson distribution.

The overall mortality experience was favourable for men, less so for women. Notable deficits occurred for deaths among men from all neoplasms and in particular from lung cancer, and in deaths from diseases of the circulatory and respiratory systems. As in the previous study of the population group, no deaths were noted from nasal or nasal sinus tumours, though in the present investigation the expected number of deaths was small $(0 \cdot 12)$.

The excess in deaths from accidents, poisonings, and violence, especially from suicide, occurred yet again and was noted for both sexes. The previous excess in non/Hodgkins lymphomas, however, was not repeated. The unexpected excess of deaths from brain cancer among male pathologists has a nominal descriptive level of significance-that is, without allowing for multiple comparisons-of $p=0.034$. Incomplete results for 1981 show a further death from malignant brain tumour and one from a benign brain tumour. It has been argued ${ }^{9}$ that benign and malignant brain tumours should be grouped together for analysis because of the clinical and pathological difficulties of distinguishing between them. In addition, death certificates in such cases

Table 1 United Kingdom pathologists' mortality 1974-80. Observed $(O)$ and expected $(E)$ with standardised mortality ratios (SMR) and $90 \%$ confidence limits

\begin{tabular}{|c|c|c|c|c|c|c|c|c|}
\hline & \multicolumn{4}{|l|}{ Men } & \multicolumn{4}{|c|}{ Women } \\
\hline & $O$ & $E$ & $S M R$ & $\begin{array}{l}\text { (90\% limit) } \\
\text { Lower-upper }\end{array}$ & $O$ & $E$ & $S M R$ & $\begin{array}{l}\text { (90\% limit) } \\
\text { Lower-upper }\end{array}$ \\
\hline $\begin{array}{l}\text { All neoplasms: } \\
\text { Digestive and peritoneum } \\
\text { Brain } \\
\text { Bladder } \\
\text { Lung } \\
\text { Leukaemia } \\
\text { Other lymphatic and haematopoietic } \\
\text { Other neoplasms } \\
\text { Circulatory system: } \\
\text { Cerebrovascular } \\
\text { Ischaemic heart disease } \\
\text { Respiratory system: } \\
\text { Bronchitis, emphysema, asthma } \\
\text { Digestive system: } \\
\text { Cirrhosis } \\
\text { Accidents, poisoning, and violence: } \\
\text { Suicide } \\
\text { All other causes } \\
\text { (Not traced) } \\
\text { All causes }\end{array}$ & $\begin{array}{c}32 \\
8 \\
4^{*} \\
2 \\
9 \\
1 \\
1 \\
7 \\
49 \\
6 \\
37 \\
5 \\
2 \\
1 \\
0 \\
13^{*} \\
7^{* *} \\
10 \\
(3) \\
110\end{array}$ & $\begin{array}{r}52 \cdot 3 \\
15 \cdot 5 \\
1 \cdot 2 \\
1 \cdot 9 \\
22 \cdot 0 \\
1 \cdot 1 \\
1 \cdot 9 \\
8 \cdot 7 \\
100 \cdot 1 \\
16 \cdot 1 \\
69 \cdot 3 \\
21 \cdot 4 \\
10 \cdot 2 \\
5 \cdot 0 \\
1 \cdot 3 \\
7 \cdot 7 \\
2 \cdot 0 \\
8 \cdot 8 \\
195 \cdot 2\end{array}$ & $\begin{array}{c}61 \\
51 \\
331 \\
107 \\
41 \\
(90) \\
(54) \\
81 \\
49 \\
37 \\
53 \\
23 \\
20 \\
(20) \\
(0) \\
170 \\
353 \\
113 \\
\\
56\end{array}$ & $\begin{array}{c}(45-82) \\
(26-93) \\
(113-758) \\
(19-337) \\
(21-71) \\
(5-429) \\
(3-254) \\
(38-152) \\
(38-62) \\
(16-74) \\
(40-70) \\
(9-49) \\
(3-62) \\
(1-95) \\
(0-240) \\
(100-269) \\
(166-662) \\
(61-192) \\
(48-66)\end{array}$ & $\begin{array}{l}7 \\
1 \\
0 \\
0 \\
0 \\
1 \\
0 \\
5 \\
3 \\
2 \\
0 \\
1 \\
1 \\
1 \\
0 \\
2 \\
2 * \\
2 \\
(2) \\
16\end{array}$ & $\begin{array}{l}4.97 \\
1 \cdot 29 \\
0.11 \\
0.08 \\
0.72 \\
0.11 \\
0 \cdot 16 \\
2.49 \\
7 \cdot 32 \\
2 \cdot 17 \\
3 \cdot 42 \\
1 \cdot 58 \\
0 \cdot 41 \\
0.51 \\
0.11 \\
0.72 \\
0.20 \\
1.15 \\
16.22\end{array}$ & $\begin{array}{r}141 \\
79 \\
(0) \\
(0) \\
(0) \\
(926) \\
(0) \\
201 \\
41 \\
92 \\
(0) \\
(63) \\
(243) \\
197) \\
(0) \\
277 \\
1015 \\
174 \\
99\end{array}$ & $\begin{array}{c}(66-265) \\
(4-368) \\
(0-2853) \\
(0-3792) \\
(0-414) \\
(47-4392) \\
(0-1872) \\
(79-422) \\
(11-106) \\
(16-291) \\
(0-88) \\
(3-300) \\
(12-1154) \\
(10-936) \\
(0-2651) \\
(49-873) \\
(180-3196) \\
(31-548) \\
(62-150)\end{array}$ \\
\hline
\end{tabular}

${ }^{*} \mathrm{p}<0.05,{ }^{* *} \mathrm{p}<0.01$ 
often simply record "brain tumour". Had this grouping been done, the expected deaths from this cause to the end of 1981 would have remained less than $2 \cdot 0$, giving an SMR exceeding 300 and a conservative $p$ value of 0.017 .

Among women, the excess of other neoplasms did not reach statistical significance. The five deaths included three from breast cancer and one each from uterine cancer and liver cancer. Infectious disease accounted for one death, a case of chronic viral hepatitis recorded as being of occupational origin. Analysis of other causes mentioned on the death certificate showed one further case of leukaemia but no other lymphatic or haemopoietic neoplasms or brain tumours.

\section{Discussion}

Any mortality study can be only as accurate as the records on which it is based. We believe that the files of the Royal College of Pathologists are extremely well maintained and in addition cover a population of doctors with at least two years "exposure" to pathology. Nevertheless, we cannot totally exclude the possibility of some uncounted deaths. Those pathologists who emigrated were not traced after emigration, and if their subsequent mortality experience differed from the home based population some bias might ensure but this bias seems unlikely to be substantial.

It is well known that working populations, especially those drawn from the higher social classes, are likely to experience a lesser overall mortality than the general population. The SMR for all causes among male pathologists of 56 reported here compares favourably with figures of 81 and 67 among male medical practitioners and social class I as a whole respectively. ${ }^{10}$ Both these figures are based on "unlinked" analysis, however, and relate only to deaths under age 65.

So far as specific causes of death are concerned the continued excess of deaths from accidents, poisonings, violence, and especially suicide, is clear and disturbing. These figures are slightly in excess of these experienced by medical practitioners as a whole. ${ }^{10}$ The reasons for such excess have been much debated but few firm conclusions drawn." Access to drugs is undoubtedly a contributing factor. In the present study drug overdoses, or other abuse, contributed to all nine deaths explicitly described as suicide and to one further death. In our previous study drugs contributed to $70 \%$ of the suicides recorded.

It is difficult to decide what, apart from chance, might be the possible cause of the excess deaths from brain cancer in this population. Social class
Table 2 Brain tumours in United Kingdom pathologists $1974-81$ by stated specialty

\begin{tabular}{|c|c|c|c|}
\hline Age & Sex & Diagnosis & Specialty \\
\hline 48 & $\mathbf{M}$ & Astrocytoma & $\begin{array}{l}\text { Clinical pathology } \\
\text { (incl haematology) }\end{array}$ \\
\hline 55 & $\mathbf{M}$ & Astrocytoma & $\begin{array}{l}\text { Haematology/blood } \\
\text { transfusion }\end{array}$ \\
\hline $\begin{array}{l}62 \\
64 \\
71 \\
73\end{array}$ & $\begin{array}{l}\mathbf{M} \\
\mathbf{M} \\
\mathbf{M} \\
\mathbf{M}\end{array}$ & $\begin{array}{l}\text { Glioma } \\
\text { Glioma } \\
\text { Glioma } \\
\text { Benign }\end{array}$ & $\begin{array}{l}\text { Haematology } \\
\text { Blood transfusion } \\
\text { Bacteriology } \\
\text { Haematology }\end{array}$ \\
\hline
\end{tabular}

gradients are relatively unimportant in this tumour (social class I SMR is 108), and there is no excess among medical practitioners as a group. ${ }^{10}$ Table 2 lists the characteristics of the six cases and it is interesting to note that although the histological spread of cases by age is unremarkable, haematology figures prominently in the stated subspecialty of the pathologists. Brain tumours exhibit some unusual epidemiological features of age incidence and cell type but few aetiological hypotheses have been postulated. Table 3 lists some of the factors that have been noted. The relevance of any to pathology staff is far from clear. Exposure to organic solvents seems a possibility and one interesting if unconfirmed report concerns a case-control study of gliomas $^{19}$ in which the cases were noted to have a threefold increased risk of a previous tuberculosis infection-a well recognised hazard to pathologists in the past. ${ }^{20}$

The previous suggestions of increased incidence of certain lymphatic neoplasms have not been confirmed in this study although, in view of the overall small numbers, the possibility of an increased risk cannot be ruled out. By contrast, the single death from viral hepatitis is tragic yet showed that the dangers of infection in the population, ${ }^{20}$ though relatively rare, can still have fatal consequences.

Formaldehyde has been postulated as a human carcinogen though the evidence to date is minimal. ${ }^{8}$

Table 3 Aetiological factors in primary brain neoplasms ${ }^{12}$

\section{First born}

Jewish

Ionising radiation

Infections: toxoplasmosis, tuberculosis, ${ }^{*}$ chickenpox

? Drugs-barbiturates*

? Immunological factors

? Familial

Genetic: Downs, neurofibromatosis, immunodeficiencies

Occupational:* Chemists-Sweden ${ }^{4}$ - UK $\mathbf{U}^{7}$

Oil refinery workers ${ }^{13}$

Petrochemical plant workers ${ }^{14}$

Vinyl chloride workers ${ }^{15} 16$

Pharmaceutical workers ${ }^{17}$

Rubber workers ${ }^{18}$

(*? Relevant to pathologists) 
Most pathologists have been exposed to formalin for part or all of their professional life though current levels of exposure are not known. In this mortality study, as in our previous one, no nasal cancers were noted and the SMR for lung cancer was significantly reduced at 41 . Such a low SMR for lung cancer is likely to be due to reduced cigarette consumption by medical practitioners. ${ }^{21}$

We thank Dr P Goldblatt of OPCS, Miss B Prideaux of the RCP, and Mr K Sullivan, Mrs C Marchant, and Mrs M Whittingham of LSHTM for help with this study, which was funded by a "small grant" from the DHSS.

\section{References}

' Reid DD. Incidence of tuberculosis among workers in medical laboratories. $\mathrm{Br}$ Med J 1957;ii:1-14.

${ }^{2}$ Harrington JM, Shannon HS. Mortality study of pathologists and medical laboratory technicians. Br Med J 1975;i:329-32.

${ }^{3}$ Li FP, Fraumeni JF, Mantel N, Miller RW. Cancer mortality in chemists. J Natl Cancer Inst 1969;43:1159-64.

${ }^{4}$ Olin GR. The hazards of a chemical laboratory environment-a study of the mortality in two cohorts of Swedish chemists. Am Ind Hyg Assoc $J$ 1978;39:557-62.

5 Vianna NJ, Polan AK, Keogh MD, et al. Hodgkins disease mortality among physicians. Lancet $1974 ;$; : 733-5.

- Williams RR, Stegens NL, Goldsmith JR. Association of cancer site and type with occupation and industry from the third national cancer survey interview. J Natl Cancer Inst 1977;59:1147-85.

${ }^{7}$ Burrows GE. Health care of people at work: screening of workers in research laboratories. J Soc Occup Med 1980;30:164-8.
${ }^{8}$ International Agency for Research on Cancer. Some industrial chemicals and dyestuffs. IARC Monogr 1982;29:345-91.

- Doll R, Peto R. The causes of cancer. Quantitative estimates of avoidable risk of cancer in the United States today. Oxford: Oxford University Press, 1981.

${ }^{10}$ Registrar General of England and Wales. Occupational mortality. The registrar general's decennial supplement for England and Wales. London: HMSO, 1978.

"Murray R. The health of doctors. J R Coll Physicians Lond 1978;12:403-15.

12 Gold EB. The epidemiology of brain tumours. In: Lilienfeld AM, ed. Reviews in cancer epidemiology. New York: Elsevier North Holland, 1981:245-92.

${ }^{13}$ Thomas TL, Waxweiler RJ, Moure-Erase R, Itaya S, Fraumeni JF. Mortality patterns among workers in three Texas oil refineries. JOM 1982;24:135-41.

14 Theriault G, Goulet L. A mortality study of oil refinery workers. JOM 1979;21:1367-70.

is Waxweiler RJ, Stringer W, Wagoner JK, et al. Neoplastic risk among workers exposed to vinyl chloride. Ann NY Acad Sci 1976;271:40-8.

${ }^{16}$ Monson RR, Peters JM. Proportional mortality among vinyl chloride workers. Lancet 1974;ii:397-8.

17 Thomas TL, Decoufle P. Mortality among workers employed in the pharmaceutical industry: a preliminary investigation. JOM 1979;21:619-23.

${ }^{18}$ Mancuso TF. Problems and perspective in epidemiological study of occupational health hazards in the rubber industry. Environ Health Perspect 1976;17:21-30.

19 Ward DW, Mattinson ML, Finn R. Association between previous tuberculosis infection and cerebral glioma. $\mathrm{Br}$ Med J 1973;i:83-4.

${ }^{20}$ Harrington JM, Shannon HS. Incidence of tuberculosis, hepatitis, brucellosis, and shigellosis in British medical laboratory workers. $\mathrm{Br}$ Med J 1976;ii:759-62.

${ }^{21}$ Doll R, Peto R. Mortality in relation to smoking: 20 years observation on male British doctors. Br Med J 1976;ii:1525-36. 